7

\title{
An Alternative Approach to Foreign Language Education in Japan with a View toward Becoming a Multicultural Society
}

\author{
Mitsunori Takakuwa
}

\subsection{Introduction}

In compulsory education in public schools in Japan, foreign language education formerly began in lower secondary schools in principle. From 2011 it was introduced in elementary schools as well. Thus Japanese students in public schools are supposed to have the chance to learn foreign languages for at least several years during their compulsory education. Nonetheless, in reality, their choices are limited: they can learn only English, not other foreign languages, under the current national curriculum. English education is the foreign language education provided in compulsory education in Japanese public schools, and other foreign language education has been neglected. However, Japanese society is not as ethnically homogeneous as it has appeared to be (Burgess, 2007; Okubo, 2008; Tsuneyoshi, 2004). There are about two million foreigners registered in Japan, and more importantly, they are from various countries and regions, including where English is not primarily used (Ministry of Justice, 2012). Thus it can be said that Japan has now become a linguistically and culturally diverse society. Should we still continue to adhere to the "English education only" policy?

This study surveys foreign language education in Japanese compulsory education under the current national curriculum. It then examines the effectiveness of foreign language education in the context of Japan as a multicultural society, with special emphasis on schools with foreign children who have no knowledge of the Japanese language. Finally, the study sets forth an alternative approach to foreign language education, which is in line with Japanese society becoming increasingly multicultural and multilingual. 


\subsection{English education as the de facto foreign language education}

In the academic year of 2011, starting in April and ending in March the following year, English education was officially introduced in elementary schools in Japan. Although the grade in which students start learning English varies from place to place, the national curriculum, or the Course of Study, for elementary schools specifies what is to be learned in grades five and six. This means that Japanese elementary school students will have started to learn English by the time they are in grade five at the latest. It should be noted that English education in elementary schools is formally called "Foreign Language Activities." Therefore, any other foreign language instead of, or in addition to, English could theoretically be taught. However, in reality, English is the choice of language as specified in the national curriculum formulated by the Ministry of Education, Culture, Sports, Science, and Technology (hereafter MEXT): "In principle English should be selected for foreign language activities" (MEXT, 2010). Thus in Japan "Foreign Language Activities" in elementary schools is practically synonymous with English education.

Japan adopts a nine-year-long compulsory education system from grade one to grade nine. Japanese students have an additional three years of "foreign" language education after graduating from elementary school. However, even at the lower secondary school level (grades seven through nine), foreign language education usually implies English education. The national curriculum for lower secondary schools lists "Foreign Languages" as the name of the subject to be taught along with other subjects, such as Japanese language, mathematics, and science. However, it is easy to recognize that only English is intended in the curriculum. There are three sections in the "Foreign Languages" curriculum for lower secondary students: overall objective, objectives and contents for each language, and lesson plan design and treatment of the contents (MEXT, 2011a). The first and third sections are brief, and much of the space is reserved for the second section. This extensive section is unevenly divided into two parts: "English" and "Other Foreign Languages." The way English education is implemented is explained in great detail. For example, one of the three subsections under the heading of "English" is "contents," which contains how four skills of English should be incorporated in language activities, how pragmatic functions of language should be treated in those activities, what phonological, lexical, or grammatical 
items of English should be taught, and how these items should be treated in class.

Compared to this detailed treatment of "English," the explanation of "Other Foreign Languages" in the same section, "Objectives and contents for each language," of the curriculum is markedly brief. Under the heading of "Other Foreign Languages" there is only one sentence, saying "Instruction for foreign languages other than English should follow the objectives and contents of English instruction" (MEXT, 2011a, p. 8). MEXT is the only agency in Japan to control education in general. As Seargeant (2009) pointed out, the Japanese educational system is highly centralized. Even when local governments set their own educational goals, they should follow the national curriculum. With the power and control that MEXT has, it specifies what to teach and how to teach it in great detail in the national curricula for academic subjects, as is the case with "English" described above. Thus, if MEXT had indeed intended to implement foreign language education other than English at the lower secondary level, it would have laid down the contents and the methodology of language teaching for other languages as well in the national curriculum. Instead, as we saw above, MEXT provided a very brief explanation in a single sentence. This lack of detailed explanation on foreign language education other than English suggests that MEXT does not take its implementation into serious consideration.

One could argue that MEXT's inclusion of this brief sentence implies that they are serious about implementing foreign language education other than English. However, this interpretation is highly unlikely, because it is practically impossible to follow the objectives and contents of English instruction when teaching other foreign languages. As mentioned above, the current national curriculum introduces English education in elementary school. The previous curriculum emphasized inculcating listening and speaking abilities in English. However, because English education would now be introduced at the elementary level, a revision was made to the curriculum such that lower secondary school students could develop their abilities in all four English language skills, because these skills would be built on the foundation of students' communication abilities, which were intended to be formed at the elementary school level (MEXT, 2011c; National Institute for Educational Policy Research, 2012). However, since foreign language activities at the elementary level are synonymous with English education, there is virtually no basis for foreign languages other than English. How can learners of a foreign language who have no knowledge of that language 
learn it effectively by following a curriculum that assumes they already have some prior knowledge of the language? This is akin to novice learners of a foreign language being forced to start their very first lesson at an intermediate level. If MEXT were serious about implementing foreign language education other than English, the organization would have developed another curriculum in which the objectives, instructions, and contents differed from those of English. Therefore, in reality, during the period of compulsory education in Japan both "Foreign Language Activities" in elementary schools and "Foreign Languages" in lower secondary schools are practiced solely through English education, and MEXT cannot be considered to be serious about implementing foreign language education other than English in compulsory education, despite the fact that Japan is a multicultural society.

\subsection{English education for whom?}

As we saw above, English education is the de facto foreign language education in the compulsory education system in Japan. It is true that English is among the most influential languages in the world today in the sense that it is primarily used in international communications in politics and businesses. However, it is also true that not everyone will be involved in such international communications. Among the biggest reasons to reallocate initial English education to elementary school level was that many Japanese people did not have good command of English even after about six to ten years of English education, including higher education, before it was introduced to elementary schools (Seargeant, 2009), and that starting to learn English at an earlier age was thought to be the solution to the Japanese people's lack of proficiency in English. That is, it was assumed that extending the period of English study would enable Japanese people to become proficient in it. This solution may work in some contexts, and may not in others. For the solution of making the period of English learning longer to work effectively, it should also be assumed that Japanese people's relatively poor English proficiency level, if indeed it exists, is due to the limited amount of time spent learning English. However, the factors that affect second language learning are more complicated (e.g. Andreou, G., Vlachos, \& Andreou, E., 2005; Ellis, 2004). If one has no contact time with a target language, one is not likely to acquire it. If one lives in an environment in which the target language is primarily used and has much contact time with it by using it daily, one is likely to acquire it. 
In this sense, increasing contact time with the target language may lead to enhancing learners' proficiency levels. But it is unknown how much contact time is enough for them to become proficient in the language on the continuum of contact time between zero and every day. Under the current national curriculum, Japanese fifth and sixth graders will experience English education for 35 periods (each a 50-minute class) per year-the same amount of time as is dedicated to "Moral Education." Would it be considered a significant amount of time to add 70 periods (roughly equaling 58 hours) of English lessons in the last two years of elementary schools?

Motivation is also an important factor in second language learning (e.g. Dörnyei, 2001; Gardner, 2010). In Japan many people do not need English to live their daily lives (Yano, 2008). Although some people may use English at work, they do not need it when buying groceries, commuting, going to hospitals, banks, or public offices, and so on. Two types of motivation can be introduced here: integrative and instrumental motivations concerning second language learning (Gardner \& MacIntyre, 1991). Some learners are interested in the target language itself, the countries or regions in which it is primarily used, and the cultures associated with those who use it. Such learners can be said to have integrative motivation to learn the target language. Other learners tend to regard the language as some instrument or tool by which they can fulfill their desires to accomplish tasks in, say, business. These learners are thought to have instrumental motivation to learn the target language. In Japan, many people whose first language is Japanese do not have to use English. In such a situation, it appears difficult to encourage learners to maintain either type of motivation long enough for them to become proficient in the target language. Of course, there are some people who were able to learn it successfully with either or both types of motivation. It is likely that language teachers are among them. Other professionals or workers who use it for their business may also have been successful in maintaining motivation to learn it (Kubota, 2011; Seargeant, 2009). However, it is not as easy to maintain motivation to learn the target language as those who have been successful in being motivated may think it is.

Terasawa (2011) pointed out that the view that Japanese people have aspirations to learn English is misleading. A large-scale social survey of $n=2,507$, which investigated the behaviors and thoughts of Japanese people based on the two-stage stratified random sampling (JGSS Research Center, n.d.), showed that about $40 \%$ of Japanese valued English skills either for their work or their personal life while the remaining of about 
$60 \%$ did not. More detailed analyses showed that, according to type of job, those who were professional workers valued English skills highly, whereas people in other occupations did not. In the "Professional" category, $69.9 \%$ of 113 male workers and $60.4 \%$ of 134 female workers put a relatively high valuation on English skills for their jobs. Also $63.7 \%$ of 113 male workers and $51.8 \%$ of 137 female workers valued English skills highly for their hobbies or personal relationships. The category of types of job that comes after "Professional" is "Managerial." In this category, $52.5 \%$ of 40 male workers and $25.0 \%$ out of four female workers valued English skills for their jobs, and $57.5 \%$ of 40 male workers and $75.0 \%$ of four female workers valued English skills highly for their hobbies or personal relationships. It should be noted here that the relatively high percentage of $75.0 \%$ may be due to the small sample sizw, that is $n=4$ for this category. Thus caution is needed to evaluate this figure. For workers in other types of job ("Agricultural," "Skilled," "Semi-skilled," "Unskilled," "Clerical," and "Sales"), the highest percentage was 54.2\% out of 168 male clerical workers who valued English skills highly. Thus it is safe to conclude that, except for those who are professional workers, the majority of Japanese people do not think English skills are important for their jobs and/or their personal lives.

From a slightly different perspective, it can be pointed out that among the parents of students who go to school and study English, the majority do not value English skills highly. The students also know that Japanese people do not need to use English in their daily lives. How can they be motivated to learn English then? It could be argued that English will be useful when visiting foreign countries or regions. However, the number of people who go overseas should be considered. Table 7.1 shows the total number of Japan's population, Japanese nationals overseas who stay overseas longer than three months, and Japanese overseas travelers (Japan National Tourism Organization, n.d.; Ministry of Foreign Affairs of Japan, 2011; Ministry of Internal Affairs and Communications, n.d.).

In Table 7.1 the number of Japanese nationals living in Japan is used to show a rough measure of how many Japanese people may need to use English after they study it under the national curriculum. Japan's total population is slightly larger than the number of Japanese nationals since the former includes other nationals living in Japan. As we can see, the number of Japanese nationals overseas is very small compared to Japanese nationals in Japan. Its ratio is less than $1 \%$. The number of Japanese overseas travelers is much larger than that of Japanese nationals overseas. Still the number of Japanese overseas travelers accounts for 
Table 7.1 Japanese population, Japanese nationals overseas, and Japanese overseas travelers

\begin{tabular}{lccc}
\hline Year & Japanese population & $\begin{array}{l}\text { Japanese nationals } \\
\text { overseas }\end{array}$ & $\begin{array}{l}\text { Japanese overseas } \\
\text { travelers }\end{array}$ \\
\hline 2001 & $125,930,000$ & 837,744 & $16,215,657$ \\
2002 & $126,053,000$ & 871,751 & $16,522,804$ \\
2003 & $126,206,000$ & 911,062 & $13,296,330$ \\
2004 & $126,266,000$ & 961,307 & $16,831,112$ \\
2005 & $126,205,000$ & $1,012,547$ & $17,403,565$ \\
2006 & $126,286,000$ & $1,063,695$ & $17,534,565$ \\
2007 & $126,347,000$ & $1,085,671$ & $17,294,935$ \\
2008 & $126,340,000$ & $1,116,993$ & $15,987,250$ \\
2009 & $126,343,000$ & $1,131,807$ & $15,445,684$ \\
2010 & $126,382,000$ & $1,143,357$ & $16,637,224$ \\
\hline
\end{tabular}

Sources: Japan National Tourism Organization (n.d.); Ministry of Foreign Affairs of Japan (2011); Ministry of Internal Affairs and Communications (n.d.)

no more than $14 \%$ of that of Japanese nationals in Japan. Of course, it is unlikely that every one of the Japanese nationals overseas and Japanese overseas travelers has to be proficient in English, since some of them may go to countries or regions where English is not used primarily. However, for the sake of discussion, let us assume that everyone in these two categories would need to use English. Still the proportion of Japanese who need English is relatively small, and the conclusion that the majority of Japanese do not need English for their daily lives is tenable. Then why do Japanese students have to study English, among other foreign languages, for at least five years of compulsory education (grades five through nine), and probably for three additional years (grades ten through twelve) in upper secondary school? Do all of them have to learn it even when the majority of them are unlikely to need it? Maybe now is the time to consider whether English education should be the de facto foreign language education in Japan.

\subsection{Diversity in Japanese society}

As we have seen so far, the majority of Japanese people do not need English for their daily lives. Are there any other foreign languages they might encounter in Japan? Table 7.2 shows the number of registered foreigners and the breakdowns by nationalities (Ministry of Justice, 2012).

As Figure 7.1 shows, the number of registered foreigners gradually increased from 2001 and peaked in 2008, when over 2.2 million foreign residents were registered. After that the number declined, and, as of 2011, just over two million foreign residents were registered (Ministry of 


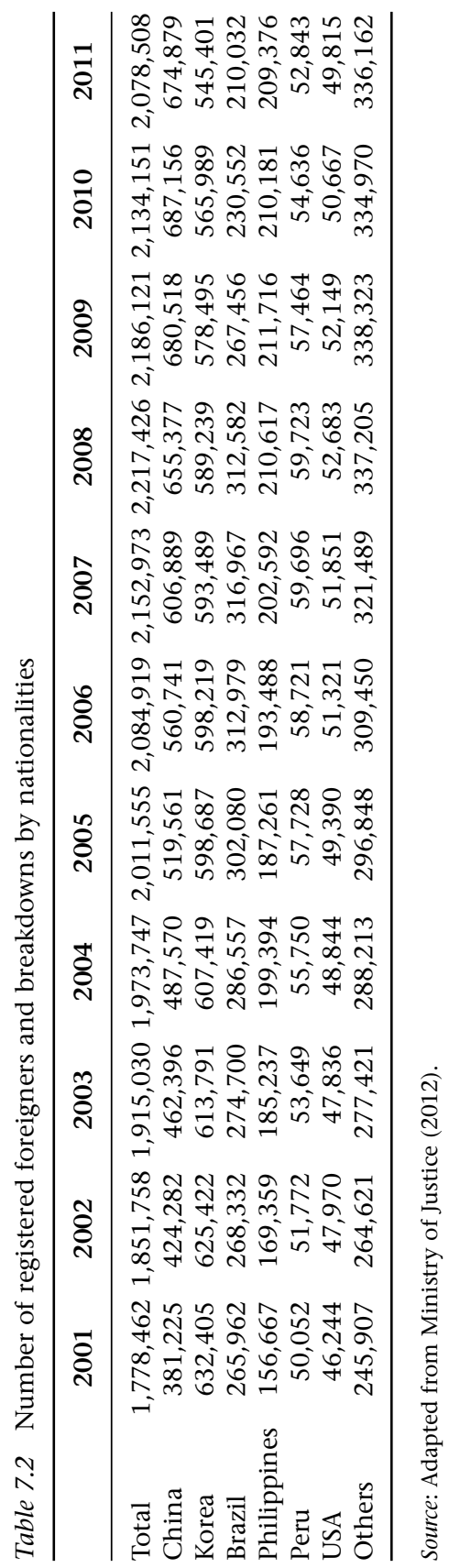




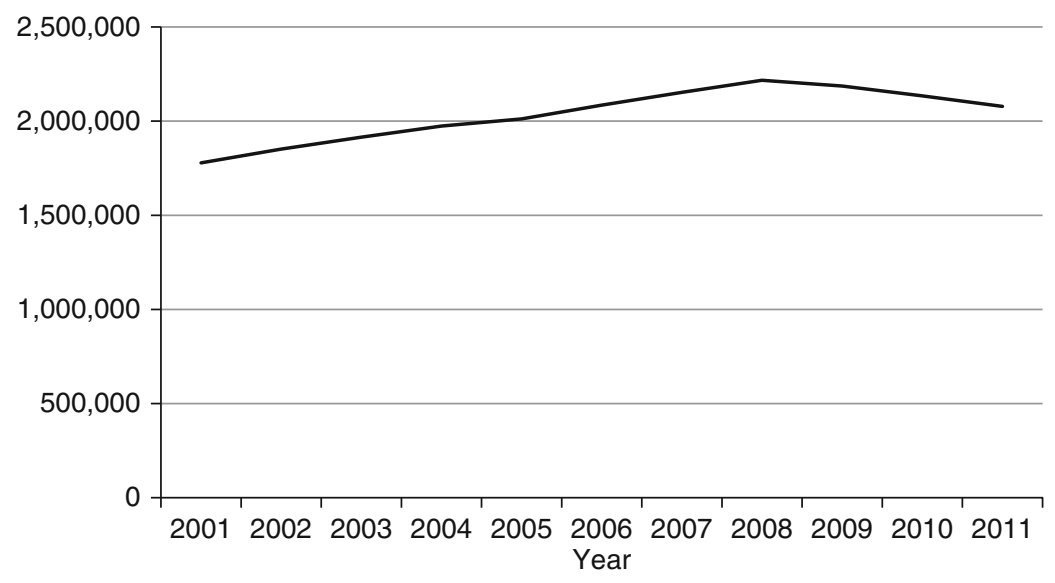

Figure 7.1 Total number of registered foreigners in Japan Source: Ministry of Justice (2012).

Justice, 2012). Out of the total number of 2,078,508 registered foreigners, Chinese constitute about 33\%, Koreans constitute about 26\%, and both Brazilians and Filipinos constitute about 10\% (see Figure 7.2).

Table 7.2 and Figures 7.1 and 7.2 show that the majority of registered foreigners originally came from Asian and South American countries. Because no data are available for the first language of these registered foreigners, we cannot be sure of which languages they use primarily. However, the fact that in these Asian and South American countries English is not primarily used as the first language of those who live there suggests that not everyone from these countries is proficient in English to the extent that they can live their daily lives using English without any difficulty. Then what would happen in terms of communication if the majority of Japanese who do not need and thus do not use English for their daily lives meet these foreigners from Asia and South American countries in Japan? Theoretically, it is possible to use English to communicate with each other. However, this type of communication requires that both parties be proficient in English. Whether the foreigners can use English or not, the majority of Japanese do not. Thus this type of communication seems rare in reality. Another scenario is for both parties to use Japanese. Anecdotally this type of communication seems much more common than the first one (Kubota \& McKay, 2009). This is not surprising in that there are many foreigners who have lived in Japan and become proficient in Japanese. Even those foreigners who are not 


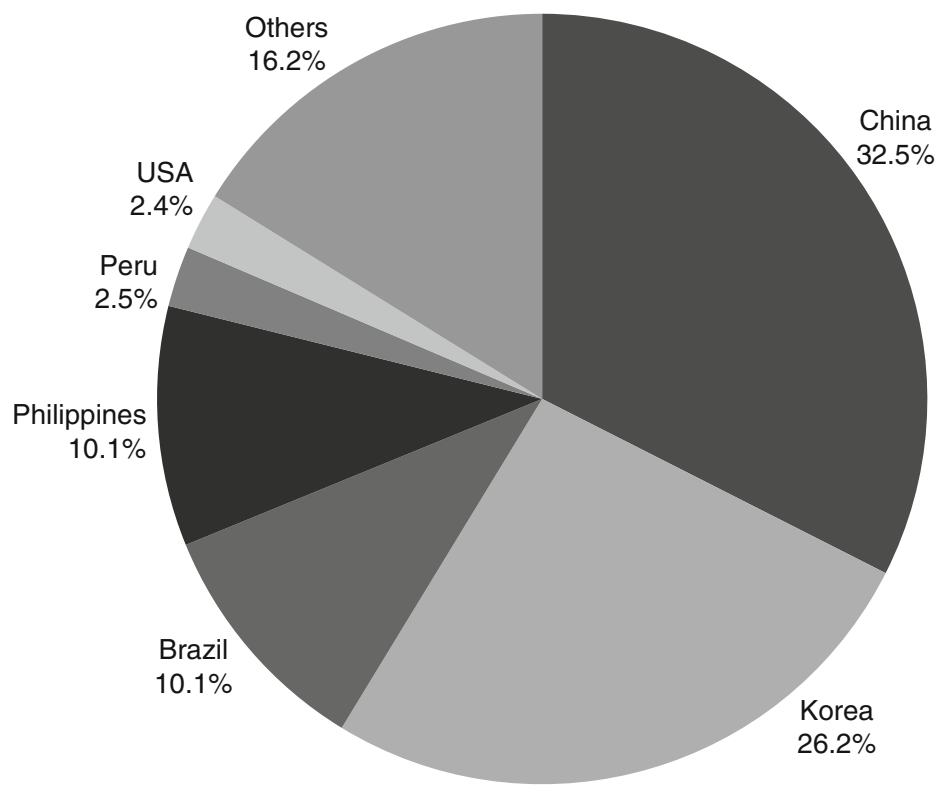

Figure 7.2 Percentage of registered foreigners by nationality in 2011 Source: Ministry of Justice (2012).

so proficient in Japanese are likely to be aware that it is primarily, and exclusively in most cases, used in Japan, and that they are expected to communicate in Japanese while they are in Japan. This type of communication is consistent with the language policy with which the Japanese government has put assimilation pressure on them (Tsuneyoshi, 2004; Vaipae, 2001). Japan has not actively accepted immigrants (Kanno, 2008; Sato, Okamoto, \& Miyao, 2009). As it is rapidly becoming an aging society (Ministry of Health, Labour and Welfare, n.d.), it seems to have come to realize that, without people from outside the country, it is very difficult to sustain such a rapidly aging society. Currently there are about two million registered foreigners, which accounts for less than $2 \%$ of Japanese population. Thus these foreigners are considered minority groups compared to the mainstream Japanese nationals. For the minority groups, about $79 \%$ of whom are people from Asian and South American countries, the Japanese government has been trying to help them acquire Japanese. Also at present many local governments, along with the Japanese government, offer important notices and instructions concerning the civil service in Chinese, Korean, Spanish, and Portuguese, as well as Japanese and English. If some areas have a 
relatively large number of other minority groups whose first language is not among those listed above, the local governments may translate notices and instructions into languages used by these groups as well or instead. However, apart from translated documents, face-to-face services in the minority languages are very limited. Such services by which foreigners will receive assistance in the civil services in their first languages are often provided by local organizations, including NGOs and NPOs, not by local governments (Burgess, 2007; Tsuneyoshi, 2004). The fact that services in minority languages are limited in Japan is not surprising given that the majority of Japanese people are not proficient even in English, which they learn at school for several years, let alone in other languages, which are virtually neglected in foreign language education in compulsory education as we saw above. However, would it not be qualified as another type of communication in the present Japan that both Japanese and foreigners should try to learn each other's language? That is, while foreigners keep learning Japanese, Japanese people could also try to learn other foreign languages in addition to English. This would allow both parties to interact with each other in two-way communication.

\subsection{Foreign language education in line with internal internationalization}

Like the English, the majority of Japanese do not need other foreign languages either since they can live their daily lives in Japanese unless they swiftly become aware of the necessity to learn foreign languages mentioned above. Thus English and other foreign languages are similar in terms of usefulness for the majority of Japanese in their daily lives. However, a difference between them can be found in terms of the number of registered foreigners living in Japan, as we saw in Figure 7.2. Although no data are available for how many of these registered foreigners actually have a language closely associated with their countries of origin as their first language, it can be safely estimated that there is at least a slightly larger chance for Japanese to encounter foreigners whose first language is, or who have a good command of, Chinese, Korean, Portuguese, or Spanish than those with English. In this sense Japan can be regarded as a multicultural and multilingual society. Thus it is just as well worth learning other foreign languages as it is to learn English. The word kokusaika, which literally means internationalization, is often heard in many contexts in Japan (Ertl, 2008). However, internationalization is usually associated with English, not with other foreign languages. This 
seems to be due to the assumption that internationalization occurs when Japanese people go abroad, that is, when the direction of internationalization is outbound. Japanese people have an image of their going abroad, and thus they come to a conclusion that they need English outside Japan. However, as we saw above, internationalization does not occur unidirectionally. The opposite form of internationalization occurs when foreigners come from outside Japan. In this type of internationalization, which is called internal internationalization (Tsuneyoshi, 2004), the direction is inbound, and knowledge of the first languages of the foreigners will enhance communication between them and Japanese people. In other words, there is a sizable conflict regarding internationalization for Japanese people. In internationalization in its traditional sense, they believe they have to use English, although this is not always true, and thus they try to learn and use it for communication with foreigners, even when they go to countries or regions in which English is not primarily used. Thus Japanese people may believe that learning English is important, and English education as the de facto foreign language subject in compulsory education in Japan supports this view. In contrast, in internal internationalization, Japanese people believe they have only to use Japanese, and English if necessary, and thus they do not try to learn other foreign languages even if the foreigners who use them as their first language outnumber those who use English as such. This may be partly because Japan tries to assimilate foreigners into Japanese society by making them learn Japanese on one hand and neglecting foreign language education other than English in the compulsory education system on the other. Implementing foreign language education other than English in compulsory education may lead to resolving this conflict.

\subsection{Foreign children in schools}

There is another valid reason to teach foreign languages other than English in the compulsory education system in Japan. As we saw above, at present there are about two million registered foreigners in Japan. The number of these figures has been decreasing slightly, partly because of the recession after the subprime mortgage crisis in 2008 and because of the Great Earthquake in Japan in 2011. However, the number of children whose first language is not Japanese and who need special assistance in the Japanese language at school has not decreased. MEXT (2011b) reported the following numbers of those children (see Table 7.3).

The numbers in Table 7.3 show students in all the public elementary schools, lower and upper secondary schools, and other types of schools, 
Table 7.3 Number of foreign children who require Japanese language instruction

\begin{tabular}{lc}
\hline Year & $\begin{array}{l}\text { Foreign children who need Japanese } \\
\text { language instruction }\end{array}$ \\
\hline 2001 & 19,250 \\
2002 & 18,734 \\
2003 & 19,042 \\
2004 & 19,678 \\
2005 & 20,692 \\
2006 & 22,413 \\
2007 & 25,411 \\
2008 & 28,575 \\
2009 & $(-)$ \\
2010 & 28,511 \\
\hline
\end{tabular}

Source: MEXT (2011b).

which include schools for the educationally challenged. Data for 2009 are missing because MEXT decided to conduct this survey every other year after 2008. A glance at this table suggests that the number of foreign students who need Japanese language instruction peaked in 2008, and it may have started to decline, given that the total number of registered foreigners peaked in 2008 and has declined since then (see Table 7.2 and Figure 7.1). However, we cannot be sure about this, since, as stated above, the data are missing for 2009 , and will be missing every other year after that, and thus we do not and will not have sufficient data to verify the interpretation of the data given above.

There is one thing we can reasonably conclude. Whether the number of foreign children who need Japanese language instruction stays the same or is decreasing, the total number of schools that host such students has increased since 2005, as in Table 7.4.

In other words, the possible decrease in numbers of such children, which might be related to the decrease in the total number of registered foreigners, does not affect the number of schools that host such students. Of course, it is possible that the number might have been higher in 2009 than in 2010, and we cannot be sure about this since no data is available for 2009. Still we can safely conclude that the number has increased since 2008, when the number of registered foreigners has, and the number of foreign students who need Japanese language instruction also seems to have, started decreasing. This brings up another issue for discussion. That is, how do schools accommodate foreign students who need Japanese language instruction? As Burgess (2007) pointed out, additional teachers are dispatched for those schools that host a certain 
Table 7.4 Number of schools hosting foreign children requiring Japanese language instruction

\begin{tabular}{lc}
\hline Year & $\begin{array}{l}\text { Schools hosting foreign children who need } \\
\text { Japanese language instruction }\end{array}$ \\
\hline 2001 & 5,296 \\
2002 & 5,130 \\
2003 & 5,231 \\
2004 & 5,346 \\
2005 & 5,281 \\
2006 & 5,475 \\
2007 & 5,877 \\
2008 & 6,212 \\
2009 & $(-)$ \\
2010 & 6,423 \\
\hline
\end{tabular}

Source: MEXT (2011b).

number of such students. This assistance does not seem sufficient, but it still is better than providing no support. About $80 \%$ of the schools that host such foreign students have four or fewer of them (MEXT, 2011b), and it is often the case that no additional teacher is dispatched for them (Burgess, 2007; Tsuneyoshi, 2004). Does having four foreign students require the school's teachers to make significantly less effort than having five of them? The line drawn between these cases is arbitrary. In fact, even having one such student requires teachers to make tremendous efforts. In the Japanese compulsory education system, at least one teacher is assigned to each class as a homeroom teacher, who takes care of the students in the class in terms not only of the students' academic progress but their school lives in general. Even when there is only one student in a class who needs Japanese language instruction, if the homeroom teacher does not speak their first language, the teacher has to make extra effort just to communicate with the student, let alone to take care of the student's school life in general. To make matters worse, it is often the case that the parent or parents of such a student may not have knowledge of the Japanese language. Thus, if the teacher wants to talk to the parent(s), an interpreter may be needed. Otherwise, negotiations between them would be likely to fail. Apparently, the teachers and the schools need much more support than they now receive from both national and local governments. Currently, local volunteers who have knowledge of the first language of the students who need Japanese instruction come to school and help them in class. However, not every school has those volunteers nearby. The most important thing is for the schools and teachers to be able to offer such support to those students. 
So how can teachers and schools systematically accommodate these students and negotiate with their parent(s) when local volunteers are not available? This is when we should come back to the discussion of foreign language education in Japan.

\subsection{Conclusion}

As we saw before, English education is the de facto foreign language taught in elementary and lower secondary schools in Japan. That is, in Japan's compulsory education system, students in public schools study English as a foreign language, but not other languages. It is true that English is widely used around the world and, thus, to learn English is potentially useful. However, the majority of Japanese can live their daily lives without it. That is, English is a language that is useful, but not always necessary, for them. If so, they do not have to learn English to the extent that they are expected to become as proficient in it as those who use it as their first language. As we saw before, Japan is now a multicultural as well as multilingual society to a certain extent. For the majority of Japanese there are slightly higher chances to communicate in languages other than English inside Japan, although the likelihood is still low. Whether the target language is English or any other foreign language, it is not easy to become as proficient in it as those who use it as their first language with merely a few years of foreign language education in the country. This is mainly due to the fact that no foreign language is prevalent in Japan. However, if we can set the goal of foreign language education as to become proficient in it to the extent that Japanese people use it according to their goals and purposes, we can safely reduce the number of class periods for English in the compulsory education system, and make room for other foreign language education.

Thus, by introducing education in other foreign languages as well, we can not only teach other foreign languages to Japanese students, but also make them realize that English is not the foreign language but simply one of the foreign languages in the world. If Japanese students have knowledge of other foreign languages, students who come from overseas and use them as their first languages may feel more comfortable at school. It is also possible that some of the Japanese students may become teachers with such knowledge and help those students who come from outside Japan in their first languages. Because Japanese society is rapidly aging, it is anticipated that an even larger number of foreigners will be needed to sustain it. This will make Japan increasingly 
multicultural and multilingual. Knowledge of foreign languages will then become key in the near future.

\section{References}

Andreou, G., Vlachos, F., \& Andreou, E. (2005). Affecting factors in second language learning. Journal of Psycholinguistic Research, 34, 429-438.

Burgess, C. (2007). "Newcomer" children in non-metropolitan public schools: The lack of state-sponsored support for children whose first language is not Japanese. Japan Forum, 19, 1-21.

Dörnyei, Z. (2001). Motivational strategies in the language classroom. Cambridge, UK: Cambridge University Press.

Ellis, R. (2004). Individual differences in second language learning. In A. Davies \& C. Elder (Eds), The handbook of applied linguistics (pp. 525-551). Malden, MA: Wiley-Blackwell,

Ertl, J. (2008). International peripheries: Institutional and personal engagements with Japan's Kokusaika movement. In: N. H. H. Graburn, J. Ertl, \& R. K. Tierney (Eds), Multiculturalism in the new Japan: Crossing the boundaries within (pp. 82-100). New York, NY: Berghahn Books.

Gardner, R. C. (2010). Motivation and second language acquisition: The socio-educational model. New York: Peter Lang.

Gardner, R. C. \& MacIntyre, P. D. (1991). An instrumental motivation in language study: who says it isn't effective? Studies in Second Language Acquisition, 13, 57-72.

Japan National Tourism Organization (n.d.). Visitor arrivals, Japanese overseas travelers. Retrieved from http://www.jnto.go.jp/jpn/reference/tourism_data/ pdf/marketingdata_outband6411.pdf

JGSS Research Center (n.d.). JGSS-2010. Retrieved from http://jgss.daishodai. ac.jp/ english/surveys/sur_jgss2010.html.

Kanno, Y. (2008). Language minority education in Japan. In A. Creese, P. Martin, \& N. H. Hornberge (Eds), Encyclopedia of language and education (Vol. 9, pp. 237-248). New York: Springer.

Kubota, R. (2011). Questioning linguistic instrumentalism: English, neoliberalism, and language tests in Japan. Linguistics and Education, 22, 248-260.

Kubota, R. \& McKay, S. (2009). Globalization and language learning in rural Japan: The role of English in the local linguistic ecology. TESOL Quarterly, 43, 593-619.

Ministry of Education, Science, and Technology (MEXT) (2010). The course of study for elementary schools: Chapter 4 foreign language activities. Retrieved from http:// www.mext.go.jp/component/a_menu/education/micro_detail/_icsFiles/ afieldfile/2010/10/20/1261037_12.pdf.

Ministry of Education, Science, and Technology (MEXT) (2011a). The course of study for lower secondary schools: Chapter 9 foreign languages. Retrieved from http:// www.mext.go.jp/component/a_menu/education/micro_detail/_icsFiles/ afieldfile/2011/04/11/1298356_10.pdf.

Ministry of Education, Science, and Technology (MEXT) (2011b). Nihongo shido ga hitsuyo na gaikokujin jidoseito no ukeirejokyoto ni kansuru chosa (Heisei 22 Nendo) no kekka ni tsuite [The results of the survey on the reception situation of foreign students who need Japanese instruction (Academic Year 2010)]. 
Retrieved from http://www.mext.go.jp/b_menu/houdou/23/08/_icsFiles/ afieldfile/2011/12/12/1309275_1.pdf.

Ministry of Education, Science, and Technology (MEXT) (2011c). The revisions of the courses of study for elementary and secondary schools. Retrieved from http://www. mext.go.jp/english/elsec/_icsFiles/afieldfile/2011/03/28/1303755_001.pdf.

Ministry of Foreign Affairs of Japan (2011). Kaigai zairyu hojinsu chosa tokei [Annual report of statistics on Japanese nationals overseas]. Retrieved from http://www.mofa.go.jp/mofaj/toko/tokei/hojin/11/pdfs/1.pdf.

Ministry of Health, Labour and Welfare (n.d.). Section 4 response to a society with a decreasing birth rate: Focusing on childrearing support measures. Retrieved from http://www.mhlw.go.jp/english/wp/wp-hw4/honbun.html.

Ministry of Internal Affairs and Communications (n.d.). Table 1. Population by sex (as of October 1 of Each Year): total population, Japanese population (from 2000 to 2010) [Data file]. Retrieved from http://www.e-stat.go.jp/SG1/estat/ Xlsdl.do?sinfid=00 0013168601.

Ministry of Justice (2012). Kokuseki (shushinchi) betsu gaikokujin torokushasu no suii [Changes in the number of registered foreign nationals by major nationality (place of origin)]. Retrieved from http://www.moj.go.jp/content/000098590.pdf.

National Institute for Educational Policy Research (2012). Lower secondary education in Japan. Retrieved from http://www.nier.go.jp/English/EducationInJapan/ Education_in_Japan/Education_in_Japan_files/201203LSJ.pdf.

Okubo, Y. (2008). "Newcomers" in public education: Chinese and Vietnamese children in a buraku community. In N. H. H. Graburn, J. Ertl, \& R. K. Tierney (Eds), Multiculturalism in the new Japan: Crossing the boundaries within (pp. 171-187). New York: Berghahn Books.

Sato, K., Okamoto, K., \& Miyao, M. (2009). Japan: Moving towards becoming a multi-cultural society, and the way of disseminating multilingual disaster information to non-Japanese speakers. Proceedings of the 2009 International Workshop on Intercultural Collaboration, USA (pp. 51-60). doi:10.1145/1499 224.1499234.

Seargeant, P. (2009). The idea of English in Japan: Ideology and the evolution of a global language. Bristol, UK: Multilingual Matters.

Tsuneyoshi, R. (2004). The "new" foreigners and the social reconstruction of difference: The cultural diversification of Japanese education. Comparative Education, 40, 55-81.

Terasawa, T. (2011). Japanese people's valuation of English skills: Sociometric analysis of JGSS-2010. JGSS Research Series, 8, 47-57.

Vaipae, S. S. (2001). Language minority students in Japanese public schools. In M. G. Noguchi, \& S. Fotos (Eds), Studies in Japanese bilingualism (pp. 184-233). Clevedon, UK: Multilingual Matters.

Yano, Y. (2008). Comment 5. World Englishes, 27, 139-140.

Except where otherwise noted, this work is licensed under a Creative Commons Attribution 3.0 Unported License. To view a copy of this license, visit http://creativecommons.org/licenses/by/3.0/ 